\title{
Biological parameters in technogenic soils of a former sulphur mine
}

\author{
Anetta Siwik-Ziomek ${ }^{1}$, Małgorzata Brzezińska ${ }^{2}$,Joanna Lemanowicz ${ }^{1}$, Jan Koper ${ }^{1}$, and Pawet Szarlip ${ }^{3}$ \\ ${ }^{1}$ Sub-Department of Biochemistry, University of Agriculture and Technology, Bernardyńska 6 ,85-021 Bydgoszcz, Poland \\ ${ }^{2}$ Institute of Agrophysics, Polish Academy of Sciences, Department of Natural Environment Biogeochemistry, \\ Doświadczalna 4, 20-290 Lublin, Poland \\ ${ }^{3}$ SHIM-POL A.M. Borzymowski, E. Borzymowska-Reszka, A. Reszka, Spółka Jawna, Izabelin, Poland
}

Received July 13, 2017; accepted December 30, 2017

\begin{abstract}
This study was conducted on the soils originating from a reclamation area of the former sulphur mine in Tarnobrzeg, Poland. Soil was sampled 16 years after the completion of mining works with the open-pit method at Machów, as well as 7 years after sulphur mining via the 'smelting' method in the Jeziórko mine was abandoned. Several biological parameters were examined: soil respiration, soil microbial biomass and the activity of rhodanese and arylsulphatase enzymes taking part in sulphur transformation within the site's soils. The soils showed a high total sulphur and sulphates content. The $\mathrm{SO}_{4}{ }^{2-}$ constituted a large fraction of total sulphur, in some cases, exceeding $80 \%$ or even $95 \%$ of total sulphur. The soil $\mathrm{pH}$ decreased due to the degrading effects of sulphur mining. In the soils studied from the locations with the lowest soil $\mathrm{pH}$ value, no activity of arylsulphatase was reported and the activity of rhodanese was lowest. The highest soil respiration values were recorded from the $0-5 \mathrm{~cm}$ layer in the areas covered with forest vegetation. A high soil respiration value at the waste heap at Machów wherein a very high concentration of $\mathrm{S}_{\text {tot }}$ and $\mathrm{SO}_{4}{ }^{2-}$ was observed can be due to the ability of fungi to produce hyphal strands and to survive unfavourable conditions.

Keywords: arylsulphatase, microbial biomass, rhodanese, soil respiration, sulphur mine
\end{abstract}

\section{INTRODUCTION}

Since the early 1990s, the sulphur industry has suffered from the increased production of sulphur from recovered sources and a low profitability of ore extraction. In mine sites, once exploitation ceased, however, several ecological problems remained to be solved. Characteristically, when waste containing sulphur minerals is exposed to oxygen and water, sulphur is oxidised to sulphates, and strong acidification takes place: $2 \mathrm{~S}+3 \mathrm{O}_{2}+2 \mathrm{H}_{2} \mathrm{O} \rightarrow 2 \mathrm{SO}_{4}{ }^{2-}+4 \mathrm{H}^{+}$. As a consequence, soil organic matter, nutrients, biota and plants can be dramatically destroyed. Along with the chemical pollution and the acidification of soils and waters, mining activities result in considerable transformations of the natural environment, including geo-mechanical and hydrological changes, negative shifts of natural vegetation, changes in landscapes and elimination of large areas from agricultural use (Levyk and Brzezińska, 2007).

In the 'Jeziórko' sulphur mine, sulphur had been recovered by way of the underground smelting method (Frasch method) since 1967. From 1967 to 2001 - more than $74 \mathrm{mln}$ $\mathrm{Mg}$ of sulphur was mined. This figure accounts for more than $58 \%$ of the total amount of the mineral recovered in the Polish sulphur deposit (Czajkowski et al., 2009). In 1964-1970, construction of the 'Machów' sulphur mine, together with the plant, was in progress. Sulphur deposit with open-pit mining in the 'Machów' open-cast started in 1969. During the mine operation, over 1969-1992, about $280 \mathrm{mln} \mathrm{m}^{3}$ of overburden was removed, about $55.8 \mathrm{mln}$ $\mathrm{m}^{3}$ of sulphur ore was recovered, and about $11.1 \mathrm{mln} \mathrm{Mg}$ of refined sulphur was produced (Szmuc and Madej, 2011). Numerous technological holes were dug out and objects were removed from the fields with heavy machinery. This resulted in significant geo-mechanical transformations and triggered destruction, transition or covering over of the upper soil horizons (Gołda et al., 2005). Additionally, in this territory, which holds a high natural groundwater level, the surface subsidence following deposit exploitation led

\footnotetext{
*Corresponding author e-mail: ziomek@utp.edu.pl
} 
to faulty aeration resulting from a low air capacity and insufficient air permeability; in some extreme cases, soils strongly soaked with water or ground water basins were formed (Bryk and Kołodziej, 2009; Gołda et al., 2005). Devastated area restoration has been driven since exploitation was stopped, including elimination of the direct industrial objects, application of sewage sludge, fertilization, neutralization with post-flotation lime, forestation, meadow management, and other specific reclamation techniques. In the open-pit, a 500 ha reservoir called 'Lake Tarnobrzeskie' was formed for recreation purposes, with a $25 \mathrm{~m}$ thick insulating clay layer at the bottom. Additionally, some limited areas were involved in self-restoration with natural plant succession in abandoned territories (Martyn and Jońca, 2006).

The increase in biological indicators so as to estimate changes in soil quality is a relevant research area. At present, it is accepted that soil biology is the driving force behind many soil processes, and that this supports the delivery of soil and soil ecosystem functions such as nutrient transformations (Creamer et al., 2014). Soil respiration measurement gives an estimate of total microbial activity in the soil. Soil basal respiration is defined as the steady rate of soil respiration (BR) which comes from organic matter mineralization (Pell et al., 2006). Basic soil respiration measurement has been applied in many different studies, and both soil microorganism respiration and organic matter mineralization are commonly accepted as indicators for measuring soil quality changes (Creamer et al., 2014).

Studies of soil enzyme activity provide information on the biochemical processes which occur in soils. Thus, biochemical soil condition has been proposed as an indicator of the real biological state of natural ecosystems (TrasarCepeda et al., 2008), as well as that of polluted soils (Tejada et al., 2015). Rhodanese (EC 2.8.1.1.) cleaves the S-S bond of thiosulphate, forming $\mathrm{S}$ and sulphite, and then $\mathrm{S}$ is subsequently oxidized into sulphite by sulphur oxygenase, while sulphite is further oxidized into sulphate by sulphite oxidase. Arylsulphatase (EC 3.1.6.1) catalyzes the hydrolysis of organic sulphate esters $\mathrm{R}-\mathrm{O}-\mathrm{SO}_{3}^{-}+\mathrm{H}_{2} \mathrm{O} \rightarrow \mathrm{ROH}+$
$\mathrm{H}+\mathrm{SO}_{4}^{2-}$ (Tabatabai and Bremner, 1970). The enzymatic activity of soil can be an indicator for monitoring the pollution of soils due to their important role in soil ecosystems.

The aim of this study was to measure several biological soil parameters that are indicators of microbial activities and soil health, in recultivation areas in Tarnobrzeg (Poland) 16 years after the end of mining works via the open-pit mining method in the Machów mine, as well as 7 years after the completion of sulphur mining by way of the 'smelting' method in the Jeziórko mine. Among such parameters, we investigated basic respiration, microbial biomass and the activities of rhodanese and arylsulphatase.

\section{MATERIAL AND METHODS}

The study involved soil sampled from the 'Machów' Sulphur Mine and the Sulphur Processing Plant at 'Machów', as well as in the vicinity of the 'Jeziórko' mine, which, together with 'Piaseczno' mine (not covered by the study), constituted the Siarkopol plant complex located near Tarnobrzeg city, south-eastern Poland $\left(50^{\circ} 34^{\prime} 22^{\prime \prime} \mathrm{N}\right.$ $21^{\circ} 40^{\prime} 45^{\prime \prime}$ ) (Fig. 1). When cheap sulphur, a petroleum processing by-product, appeared on the global markets, such mines had to be closed down. 'Machów' Sulphur Mine and Sulphur Production Plant, built in 1964-1970, were then liquidated. However, the mining fields, where sulphur was pumped out onto the surface, with time, changed into devastated areas and became almost completely deprived of vegetation.

The tested soils showed a typical post-industrial character. Technogenic soils (Technosols) are a relatively young soil group in the WRB soil system (Word Reference Base for Soil Resources); they include a variety of extremely heterogeneous soils in urban, industrial, traffic, mining and military areas (Charzyński et al., 2013). Technosols are strongly influenced by human activity and human-made materials, with properties dominated by their technical origin (Uzarowicz, 2011). Their evolution significantly depends on the duration of the pedogenesis (Ciarkowska et al., 2016), as well as on post-mine soil properties and plant cover (Józefowska et al., 2016).

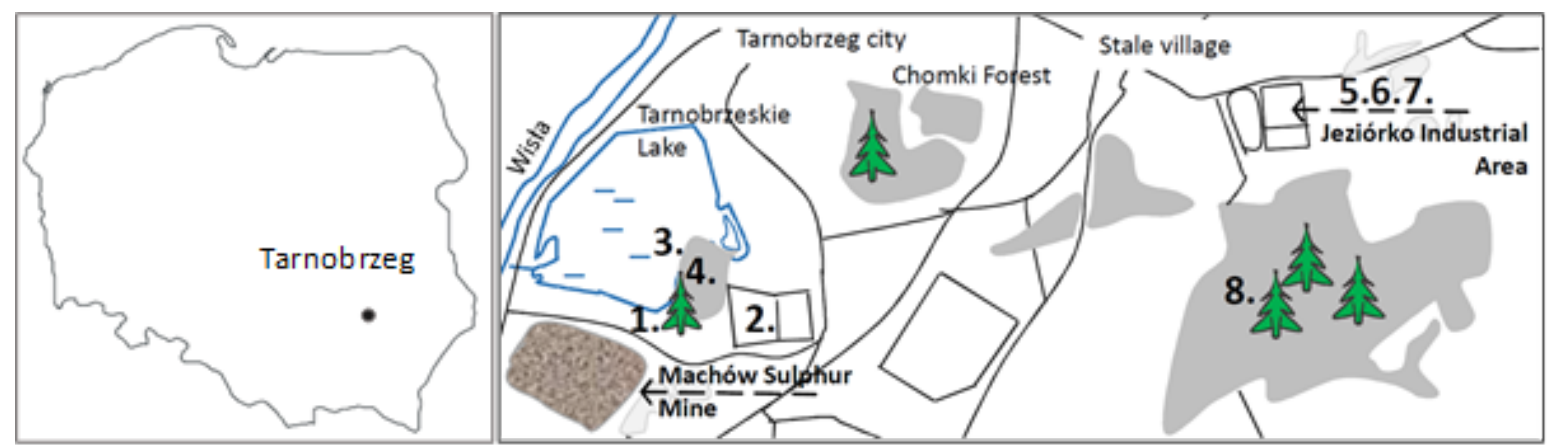

Fig. 1. Map of the studied area (left - location of Tarnobrzeg city in Poland). 1 to 4 - Open-cast mine Machów (1 - Waste-heap; 2 - Clarifier; 3 - Open-pit excavation area, ca. $200 \mathrm{~m}$ from the current border of Lake Tarnobrzeskie; 4 - Re-forested external dump). 5 to 7 - Underground melting mine Jeziórko (5, 6 and 7 - sites located 10, 20, and $40 \mathrm{~m}$, respectively, from a boring well; parcel No. XXI. 8 - Control stand (Unaffected forest ecosystem). 
Locations specific to both mining activities and the control stand were selected so as to collect soil samples. These are:

the open-cast 'Machów' mine:

- Waste-heap - a post-refining waste (called 'cake) disposal site without plant vegetation, non-reclaimed with apparent sulphur lumps up to a few $\mathrm{cm}$ in size; area of 42 ha (depth: 0-20 cm);

- Clarifier - clarifier of deposit water, a site with initial vegetation (Poaceae family); after reclamation by application of post-flotation lime; area of 13 ha (depth: 0-15 and $15-25 \mathrm{~cm}$ );

- Open-pit excavation area - the crater formed as a result of open-cast excavation. This was eliminated by filling it up with post-refining waste and covering it with a $25 \mathrm{~m}$ thick insulating clay layer obtained from an external dump (Szmuc and Madej, 2011); now with a common reed (Phragmites australis) cover, the soil was collected about $200 \mathrm{~m}$ away from the present border of Lake Tarnobrzeskie (total area of 500 ha), before the reservoir was fully filled with water, in 2009 (depth: 0-15 and $15-25 \mathrm{~cm}$ );

- Re-forest external dump - south-eastern scarp covered by spontaneously developed forest with natural succession of trees and shrubs, self-restoration area of 15 ha with a domination of Betula sp., Sorbus sp., Frangula sp.; at present on Lake Tarnobrzeskie; these heavy grounds are composed mainly of Miocene Tertiary formations (Krakowiec loams) with hard limestone, marl and marl shale intrusions, loams, and granulometric composition of clay or heavy loam (Kowalik, 2008) (depth: 3-5 and 5-30 cm).

Underground melting, borehole Jeziórko mine:

- 10, 20, and $40 \mathrm{~m}$ - post-eruption sites located 10, 20, and $40 \mathrm{~m}$, respectively, from a faulty boring well (No. T164) with uncontrolled leakage of water (parcel No. XXI with area of 100 ha); Phragmites australis plants present only around the well (at $10 \mathrm{~m}$ ), while bare ground was found $20 \mathrm{~m}$ and $40 \mathrm{~m}$ away from the well. Post-industrial soil-less formation with the particle size distribution of weakly loamy sand or sandy loam (Joniec et al., 2015; Knap et al., 2016); (depth: 0-10 and $10-20 \mathrm{~cm})$.

Control stand:

- Unaffected forest ecosystem - the control stand is located in natural deciduous forest dominated by Betula sp., Corylus sp., Populus sp., Quercus robur, and situated in the vicinity of the sulphur mine, but outside the area of direct mining activities (Nowa Dęba Forest District). The soil in this region was classified as a Haplic Gleysol developed on loamy sand (Bryk and Kołodziej, 2009); (depth: 0-10 and 10-20 cm).

In each location, a soil pit $(1 \times 1 \times 0.5 \mathrm{~m})$ was made in the representative position. Since all collected technosols were evidently post-industrial and lost their original dis- tribution of horizons, the depth of soil sampling depended on apparent differences observed in situ in the profiles. Soil was collected in three points with a specific depth, mixed, and taken to the laboratory. Next, a soil sample of about $3 \mathrm{~kg}$ for each horizon was air-dried and sieved with a $2 \mathrm{~mm}$ sieve. Basic soil properties were assayed in air-dry soils. Total sulphur $\left(\mathrm{S}_{\mathrm{tot}}\right)$ and $\mathrm{S}^{-\mathrm{SO}_{4}}{ }^{2-}$ were determined according to Bardsley-Lancaster (1960). Organic carbon $\left(\mathrm{C}_{\text {org }}\right)$ was assayed with a TOC- $\mathrm{V}_{\mathrm{CPH}}$ analyzer (Shimadzu, Japan). Soil $\mathrm{pH}$ in $\mathrm{H}_{2} \mathrm{O}$ was measured potentiometrically after $24 \mathrm{~h}$ stabilization in the soil: water ratio of 1:2.5 (w/w).

The biological properties were determined in soil samples rewetted to $60 \% \mathrm{WHC}$ and preincubated for 2 days at $20^{\circ} \mathrm{C}$. The amount of soil microbial biomass $\left(\mathrm{C}_{\text {mic }}\right)$ was defined applying the substrate induced respiration (SIR) method based on the initial respiratory response of the microbial population to amendment with an excess of glucose as an easily available carbon and energy source (Anderson and Domsch, 1973). Microbial biomass was calculated based on $\mathrm{CO}_{2}$ evolved during $2 \mathrm{~h}$ incubation with glucose $\left(5 \mathrm{mg} \mathrm{g}^{-1}\right.$ dry soil) in a water bath at $25^{\circ} \mathrm{C}$ (Šimek and Kalčik, 1998). Basal respiration rate (BR) was measured based on $\mathrm{CO}_{2}$ evolved during $24 \mathrm{~h}$ incubation at $20^{\circ} \mathrm{C}$ without the addition of $\mathrm{C}$ sources.

Concentrations of $\mathrm{CO}_{2}$ in the soil headspace were measured with a gas chromatograph Shimadzu GC-14A (Japan) equipped with a thermal conductivity detector (TCD) (Brzezińska et al., 2012). Arylsulphatase and rhodanese were determined colorimetrically according to Tabatabai and Bremner (1970), and Tabatabai and Singh (1976), respectively.

Based on microbial biomass $\mathrm{C}$ and respiration rate, an eco-physiological indicator was derived i.e. the $\mathrm{C}_{\text {mic }}: \mathrm{C}_{\text {org }}$ ratio (percent of $\mathrm{C}_{\text {mic }}$ in $\mathrm{C}_{\text {org }}$ ).

All measurements were done in three replications and the results were expressed on an oven-dry weight basis $\left(105^{\circ} \mathrm{C}, 24 \mathrm{~h}\right)$. Simple regression procedure was used to describe the correlations between measured soil properties, and one-way analysis of variance (ANOVA, post-hoc Tukey test) was used to determine significant differences between all the samples (STATISTICA 10.0 program, StatSoft Inc.).

\section{RESULTS}

The content of organic carbon in soils depended on their location and depth. Soil sampled from the Machów Wasteheap showed the lowest content of $\mathrm{C}_{\text {org }}$ at $0.44 \pm 0.12 \%$, and in soils from the Clarifier and the Open-pit, $\mathrm{C}_{\text {org }}$ was from 0.70 to $1.28 \%$. The highest content of $\mathrm{C}_{\text {org }}$ was found in the surface layer of the Forested external dump, where it accounted for $12.49 \pm 0.06 \%$ (Table 1 ). With regard to the soil sampled in the vicinity of the underground melting Jeziórko mine, the content of $\mathrm{C}_{\text {org }}$ was lower in the deeper layer in soils 10 and $20 \mathrm{~m}$ away from the boring well 
(0.65-0.74 and $1.20-1.33 \%$, respectively). In the soils $40 \mathrm{~m}$ away and in the Unaffected forest, a higher content of $\mathrm{C}_{\text {org }}$ was found in the $0-10 \mathrm{~cm}$ layer than in the deeper layer of $10-20 \mathrm{~cm}$, and it accounted for $1.36 \%$ and $4.68 \pm 0.011 \%$, respectively. The soils showed high sulphur content. The Waste-heap site soils contained $69.98 \mathrm{~g} \mathrm{~S}_{\mathrm{tot}} \mathrm{kg}^{1}$, which was 230- and 390-fold the values observed in the Unaffected forest soil i.e. 0.30 and $0.18 \mathrm{~g} \mathrm{~S}_{\mathrm{tot}} \mathrm{kg}^{-1}$ (at 0-10 and 10-20 cm depths, respectively). In other sites of the Machów opencast mine, there was up to $4.41 \mathrm{~g} \mathrm{~S}_{\mathrm{tot}} \mathrm{kg}^{-1}$ in the Clarifier. In the Jeziórko Frasch method mine, the highest $\mathrm{S}_{\text {tot }}$ of $2.68 \mathrm{~g} \mathrm{~kg}^{-1}$ was at the $10 \mathrm{~m}$ site ( 9 times more than in the Unaffected forest soil, $\mathrm{p}<0.05$ ).

$\mathrm{SO}_{4}{ }^{2-}-\mathrm{S}$ showed similar tendency of distribution in all the experimental sites, and it ranged from 29.8 to $14.6 \mathrm{mg}$ $\mathrm{kg}^{-1}$ in the Unaffected forest, to $43584.5 \mathrm{in} \mathrm{mg} \mathrm{kg}{ }^{-1}$ in the Waste-heap. A relatively low sulphate value was measured in Re-forest (84.2-66.7 $\mathrm{mg} \mathrm{kg}^{1}$ ), while $\mathrm{SO}_{4}^{2-}-\mathrm{S}$ in soils of the Clarifier and the $10 \mathrm{~m}$ sites reached greater values of 3704.5 and $919.5 \mathrm{mg} \mathrm{kg}^{-1}$, respectively.
Both, $\mathrm{S}_{\text {tot }}$ and sulphate-S were more abundant in the topsoil than in deeper layers, except for the Open-pit, as well as the 20 and $40 \mathrm{~m}$ sites. $\mathrm{SO}_{4}{ }^{2-}-\mathrm{S}$ constituted a large fraction of $\mathrm{S}_{\text {tot }}$, in some cases, exceeding $80 \%$ or even $95 \%$ of $\mathrm{S}_{\text {tot }}$ (Clarifier, 10 and $20 \mathrm{~m}$ ). In turn, in the Re-forest site, this ratio was relatively low (8-34\%), and was close to that observed for the Unaffected forest soil i.e. 8-10\%.

The mine-heap at the open-cast Machów mine showed very strong acidity and very little organic carbon $\left(\mathrm{C}_{\text {org }}\right)$ content. Waste accumulation in the Machów mine resulted in soil degradation in the place of storage and a decrease in soil $\mathrm{pH}$ in that place to the value of $0.91 \pm 0.02$. Similarly, the soil sampled 7 years after sulphur mining in the Jeziórko mine was very highly acid ( $\mathrm{pH} 1.75-2.95)$ and highly acid $(\mathrm{pH} 3.9-4.28)$ or acid $(\mathrm{pH} 4.60-4.61)$. Only the soils from the vicinity of the open-cast Machów mine Clarifier and Open-pit excavation area demonstrated a slightly alkaline reaction.

Table 1. Organic carbon, total sulphur, sulphate sulphur content, and $\mathrm{pH}$ in the investigated soils

\begin{tabular}{|c|c|c|c|c|c|c|}
\hline Localization & $\begin{array}{l}\text { Depth } \\
(\mathrm{cm})\end{array}$ & $\begin{array}{l}\mathrm{C}_{\text {org }} \\
(\%)\end{array}$ & $\begin{array}{c}\mathrm{S}_{\mathrm{tot}} \\
\left(\mathrm{g} \mathrm{kg}^{-1}\right)\end{array}$ & $\begin{array}{l}\mathrm{SO}_{4}{ }^{2-}-\mathrm{S} \\
\left(\mathrm{mg} \mathrm{kg}^{-1}\right)\end{array}$ & $\begin{array}{l}\mathrm{SO}_{4}^{2-}-\mathrm{S} \\
\left(\% \text { in } \mathrm{S}_{\mathrm{tot}}\right)\end{array}$ & $\begin{array}{c}\mathrm{pH} \\
\left(\mathrm{H}_{2} \mathrm{O}\right)\end{array}$ \\
\hline \multicolumn{7}{|c|}{ Open-cast mine Machów } \\
\hline Waste-heap & $0-20$ & $0.44 \mathrm{e} \pm 0.12$ & $69.98 \mathrm{a} \pm 0.087$ & $43584.5 \mathrm{a} \pm 331$ & 62 & $0.91 \mathrm{i} \pm 0.02$ \\
\hline \multirow[t]{2}{*}{ Clarifier } & $0-15$ & $1.14 \mathrm{c} \pm 0.01$ & $4.41 \mathrm{~b} \pm 0.122$ & $3704.5 \mathrm{~b} \pm 0.45$ & 84 & $7.75 \mathrm{~b} \pm 0.13$ \\
\hline & $15-25$ & $0.70 \mathrm{~d} \pm 0.09$ & $0.75 \mathrm{gh} \pm 0.005$ & 716.7 def \pm 12.9 & 95 & $7.73 b \pm 0.10$ \\
\hline \multirow{2}{*}{$\begin{array}{l}\text { Open-pit excavation } \\
\text { area }\end{array}$} & $0-15$ & $1.23 \mathrm{c} \pm 0.03$ & $1.61 \mathrm{~d} \pm 0.052$ & $754.7 \mathrm{def} \pm 73.8$ & 47 & $8.18 \mathrm{a} \pm 0.14$ \\
\hline & $15-25$ & $1.28 \mathrm{c} \pm 0.01$ & $1.76 \mathrm{~d} \pm 0.108$ & $956.4 \mathrm{~d} \pm 8.14$ & 54 & $8.20 \mathrm{a} \pm 0.03$ \\
\hline \multirow{2}{*}{$\begin{array}{l}\text { Re-forested external } \\
\text { dump }\end{array}$} & $0-5$ & $12.49 \mathrm{a} \pm 0.11$ & 0.99 ef \pm 0.035 & $84.2 \mathrm{~h} \pm 2.14$ & 8 & $3.09 \mathrm{f} \pm 0.07$ \\
\hline & $5-30$ & $0.85 \mathrm{~d} \pm 0.06$ & $0.20 \mathrm{i} \pm 0.007$ & $66.8 \mathrm{~h} \pm 2.12$ & 34 & $4.41 \mathrm{~cd} \pm 0.08$ \\
\hline $\begin{array}{l}\text { Distance from the } \\
\text { boring well }(\mathrm{m})\end{array}$ & \multicolumn{6}{|c|}{ Underground melting mine Jeziórko } \\
\hline \multirow[t]{2}{*}{10} & $0-10$ & $0.65 \mathrm{de} \pm 0.03$ & $2.68 \mathrm{c} \pm 0.037$ & $1548.2 \mathrm{c} \pm 46.9$ & 58 & $1.75 \mathrm{~h} \pm 0.09$ \\
\hline & $10-20$ & $0.74 \mathrm{~d} \pm 0.12$ & $1.05 \mathrm{e} \pm 0.013$ & $919.5 \mathrm{de} \pm 58.9$ & 88 & $2.12 \mathrm{~g} \pm 0.01$ \\
\hline \multirow[t]{2}{*}{20} & $0-10$ & $1.20 \mathrm{c} \pm 0.06$ & 0.84 fgh \pm 0.026 & 601.2 ef \pm 40.9 & 71 & $2.16 \mathrm{~g} \pm 0.01$ \\
\hline & $10-20$ & $1.33 \mathrm{c} \pm 0.04$ & $0.70 \mathrm{~h} \pm 0.014$ & $676.3 \mathrm{def} \pm 3.50$ & 96 & $2.95 \mathrm{f} \pm 0.03$ \\
\hline \multirow[t]{3}{*}{40} & $0-10$ & $1.36 \mathrm{c} \pm 0.01$ & $0.30 \mathrm{i} \pm 0.004$ & $216.4 \mathrm{gh} \pm 11.0$ & 72 & $3.90 \mathrm{e} \pm 0.04$ \\
\hline & $10-20$ & $0.80 \mathrm{~d} \pm 0.11$ & 0.91 efg \pm 0.020 & $495.2 \mathrm{fg} \pm 6.91$ & 54 & $4.28 \mathrm{~d} \pm 0.01$ \\
\hline & & & Control stand & & & \\
\hline \multirow{2}{*}{$\begin{array}{l}\text { Unaffected forest } \\
\text { ecosystem }\end{array}$} & $0-10$ & $4.68 \mathrm{~b} \pm 0.011$ & $0.30 \mathrm{i} \pm 0.016$ & $29.8 \mathrm{~h} \pm 0.1$ & 10 & $4.61 \mathrm{c} \pm 0.07$ \\
\hline & $10-20$ & $1.36 \mathrm{c} \pm 0.02$ & $0.18 \mathrm{i} \pm 0.001$ & $14.6 \mathrm{~h} \pm 1.2$ & 8 & $4.60 \mathrm{c} \pm 0.08$ \\
\hline
\end{tabular}

Data pairs in each of the column which do not differ statistically were marked with the same letter. 
Microbial biomass $\mathrm{C}$ was more abundant in the upper soil layers. The $\mathrm{C}_{\text {mic }}$ equalled to $1.275 \pm 0.16 \mathrm{mg} \mathrm{g}^{-1}$ in Unaffected forest topsoil, and it was even higher in Re-forest topsoil, $2.524 \pm 0.16 \mathrm{mg} \mathrm{g}^{-1}$ (Table 2). Other sites expressed significantly lower $\mathrm{C}_{\text {mic }}$ content, especially in the Waste-heap, Open-pit and $10 \mathrm{~m}$ sites.

The $\mathrm{C}_{\text {mic }}: \mathrm{C}_{\text {org }}$ ratio in the topsoils ranged from $0.58 \pm$ $0.07 \%$ in Open-pit, to $3.42 \pm 0.12 \%$ in Clarifier. Such figures are even higher than in the Unaffected forest and Re-Forest topsoils (2.75 \pm 0.33 and $2.02 \pm 0.13 \%$, respectively). The $\mathrm{C}_{\text {mic }}$ of the deeper layer showed similar or some lower percentage of $\mathrm{C}_{\text {org }}$, except for the Re-Forest site, wherein we observed a slightly higher $\mathrm{C}_{\text {mic }}: \mathrm{C}_{\text {org }}$ ratio of $2.30 \pm 0.07 \%$.

The Re-forest soil, especially in the organic layer, was characterized by a high respiration rate of $73.27 \pm 6.14 \mathrm{mg}$ $\mathrm{CO}_{2}-\mathrm{C} \mathrm{kg} \mathrm{d}^{-1}$, which was almost 3.5 higher than in the Unaffected forest $\left(21.29 \pm 1.13 \mathrm{mg} \mathrm{CO}-\mathrm{C} \mathrm{kg}^{1} \mathrm{~d}^{-1}\right)$. Additionally, the topsoils of Waste-heap and Clarifier were cha- racterized by elevated basal respiration rates of $13.96 \pm 2.55$ and $7.80 \pm 0.25 \mathrm{mg} \mathrm{CO}_{2}-\mathrm{C} \mathrm{kg}^{1} \mathrm{~d}^{-1}$, respectively. The subsoil of the forested profile also expressed relatively high BR of $8.33 \pm 0.18 \mathrm{mg} \mathrm{CO}_{2}-\mathrm{C} \mathrm{kg}^{1} \mathrm{~d}^{-1}$, however, that value was lower than that in the natural forest ecosystem (by $30 \%$, p $<0.05$ ).

The soil close to the Open-cast sulphur mine at Machów showed arylsulphatase activity ranging from 0.022 to 0.19 $\mathrm{mM} \mathrm{pNPg}{ }^{-1} h^{-1}$. The activity of such enzymes in the soils near the underground melting mine Jeziórko ranged from 0.014 to $0.176 \mathrm{mM} \mathrm{pNP} \mathrm{g}^{-1} \mathrm{~h}^{-1}$. The Waste-heap and Open -pit excavation area at Machów and the area of $10 \mathrm{~m}$ from the underground melting mine Jeziórko were characterized by undetected arylsulphatase activity. The highest activity of this hydrolase was observed in the upper horizon of soils located on the Re-forest and Unaffected forest. The activity of rhodanese as detected in all the samples of soils was very diverse and depended on the sampling locations. The highest activity of rhodanese was determined in topsoil near the

Table 2. Amount of soil microbial biomass $\left(\mathrm{C}_{\text {mic }}\right)$, ratio of $\mathrm{C}_{\mathrm{mic}}: \mathrm{C}_{\mathrm{org}}$, basal soil respiration rate (BR), and rhodanese (RDN) and arylsulphatase $(A R)$ activities in the investigated soils $(n=45, p<0.001)$

\begin{tabular}{|c|c|c|c|c|c|c|}
\hline Localization & $\begin{array}{l}\text { Depth } \\
(\mathrm{cm})\end{array}$ & $\begin{array}{c}\mathrm{C}_{\mathrm{mic}} \\
\left(\mathrm{mg} \mathrm{g}^{-1}\right)\end{array}$ & $\begin{array}{c}\mathrm{C}_{\text {mic }}: \mathrm{C}_{\text {org }} \\
(\%)\end{array}$ & $\begin{array}{c}\mathrm{BR} \\
\left(\mathrm{mg} \mathrm{CO} \mathrm{kg}^{-1} \mathrm{~d}^{-1}\right)\end{array}$ & $\begin{array}{c}\text { AR } \\
\left(\mu \mathrm{M} \mathrm{pNP} \mathrm{g}^{-1}\right. \\
\left.\mathrm{h}^{-1}\right)\end{array}$ & $\begin{array}{c}\text { RDN } \\
\left(\mu \mathrm{M} \mathrm{SCN} \mathrm{g}^{-1} \mathrm{~h}^{-1}\right)\end{array}$ \\
\hline \multicolumn{7}{|c|}{ Open-cast mine Machów } \\
\hline Waste-heap & $0-20$ & $0.077 \mathrm{e} \pm 0.01$ & $1.77 \mathrm{de} \pm 012$ & $13.96 \mathrm{c} \pm 2.55$ & n.d. & $0.122 \mathrm{i} \pm 0.014$ \\
\hline \multirow[t]{2}{*}{ Clarifier } & $0-15$ & $0.389 \mathrm{c} \pm 0.01$ & $3.42 \mathrm{a} \pm 0.12$ & 7.80 cde \pm 0.25 & $0.022 \mathrm{de} \pm 0.001$ & $1.479 \mathrm{~d} \pm 0.025$ \\
\hline & $15-25$ & $0.067 \mathrm{e} \pm 0.01$ & $0.96 \mathrm{fgh} \pm 0.17$ & 1.43 ef \pm 0.39 & n.d. & $0.621 \mathrm{~g} \pm 0.026$ \\
\hline \multirow{2}{*}{$\begin{array}{l}\text { Open-pit excavation } \\
\text { area }\end{array}$} & $0-15$ & $0.071 \mathrm{e} \pm 0.01$ & $0.58 \mathrm{~h} \pm 0.07$ & $3.25 \operatorname{def} \pm 0.09$ & n.d. & $1.810 \mathrm{c} \pm 0.075$ \\
\hline & $15-25$ & $0.067 \mathrm{e} \pm 0.01$ & $0.52 \mathrm{~h} \pm 0.01$ & $2.00 \operatorname{def} \pm 0.17$ & n.d. & $1.932 \mathrm{~b} \pm 0.015$ \\
\hline \multirow{2}{*}{$\begin{array}{l}\text { Re-forested external } \\
\text { dump }\end{array}$} & $0-5$ & $2.524 \mathrm{a} \pm 0.16$ & $2.02 \mathrm{~cd} \pm 0.13$ & $73.27 \mathrm{a} \pm 6.14$ & $0.190 \mathrm{a} \pm 0.005$ & $5.885 \mathrm{a} \pm 0.02$ \\
\hline & $5-30$ & 0.195 cde \pm 0.01 & $2.30 \mathrm{bcd} \pm 0.07$ & $8.33 \mathrm{~cd} \pm 0.18$ & $0.036 \mathrm{~cd} \pm 0.001$ & $0.723 \mathrm{~g} \pm 0.033$ \\
\hline $\begin{array}{l}\text { Distance from the } \\
\text { boring well }(\mathrm{m})\end{array}$ & \multicolumn{6}{|c|}{ Underground melting mine Jeziórko } \\
\hline \multirow[t]{2}{*}{10} & $0-10$ & $0.081 \mathrm{e} \pm 0.01$ & $1.25 \mathrm{efg} \pm 0.04$ & $1.30 \mathrm{f} \pm 0.09$ & n.d. & $0.867 \mathrm{f} \pm 0.005$ \\
\hline & $10-20$ & $0.060 \mathrm{e} \pm 0.01$ & $0.81 \mathrm{gh} \pm 0.05$ & 1.34 ef \pm 0.03 & n.d & $0.340 \mathrm{~h} \pm 0.016$ \\
\hline \multirow[t]{2}{*}{20} & $0-10$ & $0.163 \mathrm{de} \pm 0.01$ & 1.36 efg \pm 0.08 & $4.89 \mathrm{def} \pm 0.28$ & $0.045 \mathrm{c} \pm 0.002$ & $1.026 \mathrm{e} \pm 0.015$ \\
\hline & $10-20$ & $0.074 \mathrm{e} \pm 0.01$ & $0.56 \mathrm{~h} \pm 0.01$ & $2.06 \mathrm{def} \pm 0.35$ & n.d. & $0.677 \mathrm{~g} \pm 0.04$ \\
\hline \multirow[t]{3}{*}{40} & $0-10$ & 0.190 cde \pm 0.04 & 1.40 ef \pm 0.27 & $4.23 \operatorname{def} \pm 0.19$ & 0.018 e \pm 0.001 & 0.977 ef \pm 0.025 \\
\hline & $10-20$ & $0.108 \mathrm{e} \pm 0.02$ & $1.34 \mathrm{efg} \pm 0.24$ & $2.54 \operatorname{def} \pm 0.12$ & $0.014 \mathrm{e} \pm 0.002$ & $0.671 \mathrm{~g} \pm 0.06$ \\
\hline & & & Control stand & & & \\
\hline \multirow{2}{*}{$\begin{array}{l}\text { Unaffected forest } \\
\text { ecosystem }\end{array}$} & $0-10$ & $4.68 \mathrm{~b} \pm 0.011$ & $0.30 \mathrm{i} \pm 0.016$ & $29.8 \mathrm{~h} \pm 0.1$ & 10 & $4.61 \mathrm{c} \pm 0.07$ \\
\hline & $10-20$ & $1.36 \mathrm{c} \pm 0.02$ & $0.18 \mathrm{i} \pm 0.001$ & $14.6 \mathrm{~h} \pm 1.2$ & 8 & $4.60 \mathrm{c} \pm 0.08$ \\
\hline
\end{tabular}

Data pairs in each of the column which do not differ statistically were marked with the same letter, n.d. - not detected. 
Table 3. Relation between investigated parameters. Correlation coefficients (R) with bold-face are significant at $p \leq 0.05(n=45)$

\begin{tabular}{|c|c|c|c|c|c|c|c|c|c|}
\hline Treatment & $\mathrm{C}_{\text {org }}$ & $\mathrm{S}_{\mathrm{tot}}$ & $\mathrm{SO}_{4}^{2-}-\mathrm{S}$ & $\mathrm{pH}$ & $\mathrm{C}_{\mathrm{mic}}$ & $\mathrm{C}_{\mathrm{mic}}: \mathrm{C}_{\mathrm{org}}$ & $\mathrm{BR}$ & AR & $\mathrm{RDN}$ \\
\hline $\mathrm{C}_{\text {org }}$ & 1 & & & & & & & & \\
\hline $\mathrm{S}_{\mathrm{tot}}$ & -0.150 & 1 & & & & & & & \\
\hline $\mathrm{SO}_{4}^{2-}-\mathrm{S}$ & -0.165 & 0.999 & 1 & & & & & & \\
\hline $\mathrm{pH}$ & -0.105 & -0.378 & -0.371 & 1 & & & & & \\
\hline $\mathrm{C}_{\text {mic }}$ & 0.976 & -0.130 & -0.143 & -0.102 & 1 & & & & \\
\hline $\mathrm{C}_{\text {mic }}: \mathrm{C}_{\text {org }}$ & 0.248 & 0.075 & 0.083 & 0.006 & 0.419 & 1 & & & \\
\hline $\mathrm{BR}$ & 0.962 & 0.043 & 0.029 & -0.185 & 0.952 & 0.352 & 1 & & \\
\hline AR & 0.722 & -0.313 & -0.417 & -0.211 & 0.778 & 0.286 & 0.723 & 1 & \\
\hline RDN & 0.943 & -0.239 & -0.253 & 0.125 & 0.896 & 0.180 & 0.889 & 0.641 & 1 \\
\hline
\end{tabular}

$\mathrm{BR}$ - basal respiration, $\mathrm{AR}$ - arylsulphatase activity, $\mathrm{RDN}$ - rhodanese activity.

open-cast Machów Re-forest (5.885 $\left.\mu \mathrm{M} \mathrm{SCN}^{-} \mathrm{g}^{-1} \mathrm{~h}^{-1}\right)$ and it was 3-fold higher than was rhodanese from the upper horizon soil from the Unaffected forest $\left(1.822 \mu \mathrm{M} \mathrm{SCN}^{-} \mathrm{g}^{-1} \mathrm{~h}^{-1}\right)$. Rhodanese activity of the upper horizon $(0-10 \mathrm{~cm})$ of the profile at the Jeziórko mine was 30\% higher than soil from the depth of $10-20 \mathrm{~cm}$ (20 and $40 \mathrm{~m}$ ) and $60 \%$ higher when $10 \mathrm{~m}$ away from the mine.

The inter-relations between the measured soil properties are provided in Table 3 . Organic $\mathrm{C}$ is positively and significantly correlated with $\mathrm{C}_{\text {mic }}(\mathrm{R}=0.976, \mathrm{p}<0.001)$. Organic $\mathrm{C}$ also shows positive correlation with $\mathrm{BR}(\mathrm{R}=0.962$, $\mathrm{p}<0.001)$. Organic carbon promotes microbial activity so it was significantly correlated between $\mathrm{C}_{\text {org }}$ and enzymes activity: arylsulphatase $(\mathrm{R}=0.722, \mathrm{p}<0.001)$ and rhodanese activity $(\mathrm{R}=0.942, \mathrm{p}<0.001)$.

\section{DISCUSSION}

Soil $\mathrm{pH}$ is an important parameter influencing soil surface chemistry and determining cation and anion adsorption onto oxide minerals. Soil pH near the open-cast Machów mine and Jeziórko mine varied with depth and distance from the mine. Elementary sulphur is chemically inactive, only when it oxidises and bonds, it forms sulphuric acid contributing to degrading soil acidification. At all sites near the Jeziórko mine, $\mathrm{pH}$ increased with soil depth (Table 1). The model studies performed in the 1980 s by Siuta (1982) in the Jeziórko mine demonstrated that as little as $2 \%$ addition of sulphur after 14 days results in a decrease in soil $\mathrm{pH}$ from 6.0 to 5.3, and after the third month of the experiment, down to 1.9. According to Urlich et al. (1980), one can assume that natural acidification is caused in soils by weak acids, mostly carbonic acid and various organic acids. It is assumed that they can decrease the soil reaction to the value $\mathrm{pH} \mathrm{KCl}>5.0$. However, the occurrence of strong acids, e.g. $\mathrm{H}_{2} \mathrm{SO}_{4}$, in soil due to anthropogenic reasons decreases the reaction $\mathrm{pH} \mathrm{KCl<5.0.} \mathrm{One} \mathrm{can,} \mathrm{therefore,} \mathrm{assume} \mathrm{that} \mathrm{even}$ in the forest, the soil $\mathrm{pH}$ decreased due to the degrading effect of sulphur mining by smelting, which miners consider an eco-friendly method, as compared to its traditional openpit recovering. The recultivated areas around the Machów mine, on the other hand, show higher, slightly alkaline $(\mathrm{pH}$ 7.73-7.75) and alkaline ( $\mathrm{pH} 8.18-8.20) \mathrm{pH}$ values. Liming in the Machów region was common and involved a successive supply of inconsiderable calcium fertiliser rates $(\mathrm{CaO}$ and $\mathrm{CaCO}_{3}$ ) within a few years or introducing a homogeneous single preventive rate.

According to the scale of the limit, in the sulphur contents within the surface soil layers (Motowicka-Terelak and Terelak, 1998) both as (S) and $\left(\mathrm{SO}_{4}{ }^{2-}-\mathrm{S}\right)$, in all the cases studied, its excess is recorded due to human impact. A long persistence of easily leaching sulphur compounds in soils, namely 16 years after mining in the Machów mine was neglected and 7 years after the Jeziórko mine was closed down, accounts for the formation of sulphate minerals. González et al. (2011) found that in the periods of high evaporation, when exposed to low $\mathrm{pH}$ values and a relatively high concentration of soluble salts present in mining waste, mostly ions $\left(\mathrm{SO}_{4}{ }^{2-}, \mathrm{Al}^{3}\right.$ and $\left.\mathrm{Mg}^{2}\right)$, as well as trace elements $\left(\mathrm{Zn}^{2}, \mathrm{Cd}^{2}, \mathrm{~Pb}^{2}\right)$, more or less complex sulphate minerals get formed. During precipitation, secondary salt deposits dissolve, thus contributing to a very low $\mathrm{pH}$ value and a release of ions $\mathrm{Mg}, \mathrm{Al}$ and $\mathrm{Zn}$, and mostly $\mathrm{SO}_{4}{ }^{2-}$. The theory is confirmed by the results reported by Martyn and Jońca (2006), who found that waters from the mine area showed that the presence of sulphates in the waters under study exceeds the norms for their economic use potential. In the former mine waters, high amounts of total iron were identified (Martyn and Jońca, 2006). The percentage share of $\mathrm{SO}_{4}{ }^{2-}-\mathrm{S}$ in the total sulphur content in most soils (except for $40 \mathrm{~m}$-site and Unaffected Forest control soil) also increased gradually with depth and accounted for even $96 \%$ of the total sulphur content (at the 20 m-site from the 
underground Jeziórko mine) (Table 1). Today, due to a lack of influx of elementary sulphur to the soils under study, the accumulation of sulphates in deeper layers must have been due to their leaching from the upper profile part.

Sulphur recovery results in unfavourable geomorphological transformations, in changes in the existing hydrological systems (Bryk and Kołodziej, 2009) and in chemical pollution. Chemical contamination with sulphur compounds occurs not only in the place of open-cast mining or boring, but also, in the case of sulphur smelting from deposits, the compounds of that element penetrating into waters and the ground in an uncontrolled way. The highest accumulation of sulphates in the waste zone at the opencast Machów mine decreased the soil reaction to $\mathrm{pH} 0.91$. Such low soil pH results in a loss in capacity for growth and development of living organisms, and this was confirmed in practice as a lack of any vegetation in that area. In our studies, from the point with such low soil $\mathrm{pH}$, no activity of arylsulphatase was assayed and the activity of rhodanese was lowest. Soil enzyme activities are sensitive to stress in ecosystems and have the potential to serve as an indicator of the health and sustainability of ecosystems (Trasar-Cepeda et al., 2008). Enzymatic activities can reflect the biological state in the soil (Igbinosa, 2015). Indeed, Wainwright (1979) shows that rhodanese activity was higher in polluted than in unpolluted soils. The results indicate that microbial S-oxidation occurs in soils exposed to heavy atmospheric pollution. According to Wainwright (1979), polluted soils contained more fungi (total count) than unpolluted soils, as well as fewer heterotrophic bacteria (total count). Thus, the different reaction of rhodanese, as compared with the activity of arylsulphatase, may come from the fact that it is produced by fungi (Szajdak, 2003), and the metabolic processes of such microorganisms can express a different pattern than that of the bacteria which are a source of arylsulphatases in soils (Knauff et al., 2003).

According to Anderson (2003), the $\mathrm{C}_{\text {mic }}: \mathrm{C}_{\text {org }}$ of agricultural and forest soils at neutral $\mathrm{pH}$ is very similar and in the range between 2.0 and $4.4 \%$. Values below 2.0 for the $\mathrm{C}_{\text {mic }}: \mathrm{C}_{\text {org }}$ could be considered as critical for soils with a neutral soil $\mathrm{pH}$. Under acidic conditions, the cell-internal $\mathrm{pH}$ (which needs to be kept around 6.0) diverges from the surrounding $\mathrm{pH}$ conditions, and, accordingly, little biomass can be produced. This is reflected in low $\mathrm{C}_{\text {mic }}: \mathrm{C}_{\text {org }}$. In our studies, the lowest $\mathrm{C}_{\text {mic }}: \mathrm{C}_{\text {org }}$ were reported in soils sampled from the areas where we observed low $\mathrm{pH}$ (the waste-heap in open-cast mine Machów and the 10, 20, $40 \mathrm{~m}$ sample sites in the underground melting mine Jeziórko) but also where we saw high $\mathrm{pH}$ (Clarifier- at $0-15 \mathrm{~cm}$ and in the Open-pit excavation area). The area with forest vegetation (Re-forest, External dump and Unaffected forest ecosystems) have $\mathrm{C}_{\text {mic }}: \mathrm{C}_{\text {org }}$ above $2 \%$, whereby the carbon is available for soil microbial community growth (Anderson, 2003). A lack of significant correlation between the $\mathrm{C}_{\text {mic }}: \mathrm{C}_{\text {org }}$ and $\mathrm{C}_{\text {org }}$ (Table 3 ) confirms the disturbance of soil habitats in the tested technogenic soils. Nevertheless, microbial biomass $\mathrm{C}_{\text {mic }}$ showed a high positive relationship with arylsulphatase and rhodanese activities.

The major factors influencing soil respiration include soil moisture affecting the overall microbial activity as a source of $\mathrm{CO}_{2}-\mathrm{C}$ efflux, soil diffusion kinetics and the existing relationship between efflux diffusion through the soil (Goupil and Nkongolo, 2014). According to Kuzyakov and Gavrichkova (2010), underground root and microbial respiration are greatly promoted by aboveground photosynthesis. Li et al. (2004) estimated the contribution of aboveground litter to total soil $\mathrm{CO}_{2}$-C. In our studies, the highest $\mathrm{BR}$ values were reported in soil $0-5 \mathrm{~cm}$ layer sampled from the areas covered with forest vegetation. The Machów forested external dump was a three and a half times less unaffected forest ecosystem than that of Jeziórko. Ramesh et al. (2008) in their studies, revealed that water holding capacity depended on the level of organic carbon. Presumably, the highest organic carbon content (12.49 in Machów and 4.68 in Jeziórko) and the highest $\mathrm{C}_{\text {mic }}$ in both places (2.524 and $1.275 \mathrm{mg} \mathrm{g}^{-1}$ ) influenced the basic respiration by increasing holding capacity and microbial biomass and enzyme activity. In both places, we found the highest activity of arylsulphatase and rhodanese (Table 2). Soil depth is a soil parameter which can be considered to account for soil respiration. Indeed, soil depth could control the root zone water availability (Cable et al., 2008), and, consequently, affect the plant, microbial and enzyme activity. Environmental stresses brought about by mining activities and contamination by sulphur in the forest sites, as compared to places near the mine, could be responsible for the reduction in microbial population and diversity (Monson et al., 2006). Only the waste-heap site in the open-cast mine Machów surprised us with its high basal respiration (13.96 mg CO $\left.\mathrm{kg}^{-1} \mathrm{~d}^{-1}\right)$. This may be due to abiotic organic carbon mineralization. Presumably in the soil with the highest total sulphur and sulphate content where the activity of rhodanese was observed, the soil fungi have the ability to produce hyphal strands. Such adaptability is to help survival under unfavourable conditions.

\section{CONCLUSIONS}

1. This study has shown that the kind of sulphur mining has a long-term influence on soil quality and enzyme activity.

2. Soil acidity is a major challenge in the study sites and requires liming or wood ash application.

3. The microbial stress associated with acidity, and high sulphur content lower the activity of arylsulphatase and rhodanese. The basic respiration is correlated to $\mathrm{C}_{\text {org, }}$, $\mathrm{C}_{\text {mic }}$ and enzyme activities, which suggests that the effect of microorganisms on respiration should be significant and direct. 


\section{ACKNOWLEDGEMENTS}

The authors thank E. Świca, K. Szafraniec, and especially W. Warzybok ('Machów' Sulphur Mine in Tarnobrzeg, Poland) for their help and valuable information during soil sample collection.

Conflict of interest: The Authors do not declare conflict of interest.

\section{REFERENCES}

Anderson T.H., 2003. Microbial eco-physiological indicators to assess soil quality. Agric. Ecosyst. Environ., 98, 285-293.

Anderson J.P.E. and Domsch K.H., 1973. Selective inhibition as a method for estimation of the relative activities of microbial populations in soils. Bulletins Ecological Res. Committee (Stockholm), 17, 281-282.

Bardsley C.E. and Lancaster J.D., 1960. Determination of reserve sulfur and soluble sulfates in soil. Soil Sci. Soc. Am. Proc., 24, 265-268.

Bryk M. and Kołodziej B., 2009. Reclamation problems for the area of a former borehole sulfur mine with particular reference to soil air properties. Land Degrad. Dev., 20, 509-521.

Brzezińska M., Nosalewicz M., Pasztelan M., and Włodarczyk T., 2012. Methane production and consumption in loess soil at different slope position. Sci. World J., Article ID 620270.

Cable J.M., Ogle K., Williams D.G., Weltzin J., and Huxman T.E., 2008. Soil texture drives responses of soil respiration to precipitation pulses in the Sonoran Desert: implications for climate change. Ecosystems, 11, 961-979.

Charzyński P., Bednarek R., Greinert A., Hulisz P., and Uzarowicz L., 2013. Classification of technogenic soils according to WRB system in the light of Polish experiences. Soil Sci. Annual, 64, 145-150.

Ciarkowska K., Gargiulo L., and Mele G., 2016. Natural restoration of soils on mine heaps with similar technogenic parent material: A case study of long-term soil evolution in Silesian-Krakow Upland Poland. Geoderma, 261, 141-150.

Creamer R.E., Schulte R.P.O., Stone D., Gal A., Krogh P.H., Papa G., Lo Murray P.J., Pérès G., Foerster B., Rutgers M., Sousa J.P., and Winding A., 2014. Measuring basal soil respiration across Europe: do incubation temperature and incubation period matter? Ecol. Indic., 36, 409-418.

Czajkowski R., Dzieidzic W., Kostuch R., and Maślanka K., 2009. Estimation of selected elements of environment on recultivated terrains of sulphur mine 'Jeziórko' (in Polish). Acta Sci. Pol., 13(1), 3-18.

Gołda T., Haladus A., and Kulma R., 2005. Geosozologiczne skutki likwidacji kopalni siarki w rejonie Tarnobrzega. (in Polish) Inżynieria Środowiska, 10, 59-73.

González V., García I., del Moral F., de Haro S., Sánchez J.A., and Simón M., 2011. Impact of unconfined sulphur-mine waste on a semi-arid environment (Almería, SE Spain). J. Environ. Manag., 92, 1509-1519.

Goupil K. and Nkongolo K., 2014. Assesing soil respiration as an indicator or of soil microbial activity inreclamed metal contamined lands. Am. J. Environ. Sci., 10(4), 403-411.
Igbinosa E.O., 2015. Effect of cassava mill effluent on biological activity of soil microbial community. Environ Monit Assess 187, 418, doi:10.1007/s10661-015-4651-y

Joniec J., Fruczak J., and Kwiatkowska E., 2015. Application of biological indicators for estimation of remediation of soil degraded by sulphur industry. Ecological Chemistry Eng. S, 22, 269-283.

Józefowska A., Woś B., and Pietrzykowski M., 2016. Tree species and soil substrate effects on soil biota during early soil forming stages at afforested mine sites. Appl. Soil Ecol., 102, 70-79.

Knap R., Kaniuczak J., Hajduk E., Szewczyk A., 2016. Properties of degraded and reclaimed soils in the area of the abandoned 'Jeziórko' sulfur mine (Poland). Soil Sci. Ann., 67, 163-172.

Knauff U., Schulz M., and Scherer H.W., 2003. Arylsulfatase activity in the rhizosphere and roots of different crop species. Eur. J. Agron., 19, 215-223.

Kowalik S., 2008. The problem of phosphorus in the agricultural reclamation of very compact grounds in the heap of sulfur mining (in Polish). Research Paper of Wroclaw University of Economics, 4(1204), 49-59.

Kuzyakov Y. and Gavrichkova O., 2010. Time lag between photosynthesis and carbon dioxide efflux from soil: A review of mechanisms and controls. Global Change Biology, 16, 3386-3406.

Levyk V. and Brzezińska M., 2007. The state of soil cover on the territories of former sulphur mines "Yavoriv" (Ukraine) and "Machów" (Poland) from the standpoint of current research. Acta Agrophys., 10(1), 149-157.

Li Y., Xu M., Sun O.J., and Cui W., 2004. Effects of root and litter exclusion on soil $\mathrm{CO}_{2}$ efflux and microbial biomass in wet tropical forests. Soil Biol. Bioch., 36, 2111-2114.

Martyn W. and Jońca M., 2006. Selected chemical properties of surface waters in the area of former sulphur mine" Jeziórko" as an indicator of condition of environment after reclamation of mining areas (in Polish). Acta Agrophys., 8(2), 449-458.

Monson R.K., Lipson D.L., and Burns S.P., 2006. Winter forest soil respiration controlled by climate and microbial community composition. Nature, 439, 711-714.

Motowicka-Terelak T. and Terelak H., 1998. Sulphur in soils of Poland - the status and the risks (in Polish). Bibl. Monit. Środ., PIOŚ, Warszawa, Poland.

Pell M., Stenström J., and Granhall U., 2006. Soil Respiration. In: Microbial Methods for Assessing Soil Quality (Eds J. Bloem, D.W. Hopkins, A. Benedetti). CAB International, Wallingford, Oxfordshire, UK.

Ramesh V., Ballol S.S., Sharma K.L., Kausalya R., Korwar G.R., and Ramakrishna Y.S., 2008. Characterization of soil for physical properties under different land use systems. Indian J. Dryland Agric. Res. Dev., 23(1), 102-109.

Siuta J., 1982. Soil protection (in Polish). Institute of Environmental Shaping, Warsaw, Poland.

Szmuc M. and Madej K., 2011. There was a sulphur! What is now? (in Polish). Górnictwo i Ekologia, 6(1), 211-221.

Szajdak L., 2003. impact of continuous cropping of rye on the activity of rhodanese and the quantity of free sulfuric amino acids in soils. Fertilizers Fertilisation, 1, 82-91. 
Šimek M. and Kalčik J., 1998. Carbon utilization in soils: the effect of long-term fertilization on potential denitrification. Geoderma, 83, 269-280.

Tabatabai M.A. and Bremner J.M., 1970. Factors affecting soil arylsulphatase activity. Soil Sci. Soc. Amer. Proc., 34, 427-429.

Tabatabai M.A. and Singh B.B., 1976. Rhodanese activity of soils. Soil Sci. Soc. Am. J., 40, 381-385.

Tejada M., García C., Hernández T., and Gómez, I., 2015. Response of soil microbial activity and biodiversity in soil polluted with different concentrations of cypermethrin insecticide. Arch. Environ. Contam. Toxicol., 69, 8-19.

Trasar-Cepeda C., Leirós M.C., and Gil-Sotres F., 2008. Hydrolytic enzyme activities in agricultural and forest soils. Some implications for their use as indicators of soil quality. Soil Biol. Bioch., 40, 2146-2155.
Urlich B., Mayer R., and Khanna P.K., 1980. Chemical changes due to acid precipitation in a loess derived soil in central Europe. Europ. Soil Sci., 130, 193-199.

Uzarowicz Ł., 2011. Technogenic soils developed on mine spoils containing iron sulfides in select abandoned industrial sites: Environmental hazards and reclamation possibilities. Polish J. Environ. Stud., 20, 771-782.

Wainwright M., 1979. Microbial S-oxidation in soils exposed to heavy atmospheric pollution. Soil Biol. Bioch., 11(2), 95-98.

Wójcik J. and Kowalik S., 2014. The content of the organic carbon and total nitrogen in the soil of the reclaimed repository of the Sulphur Mine "Machów" after many years of agricultural and forestry management. Geomat. Environ. Engin., $8,91-101$. 